\title{
Héloïse d’Argenteuil se filosofiese uitset
}

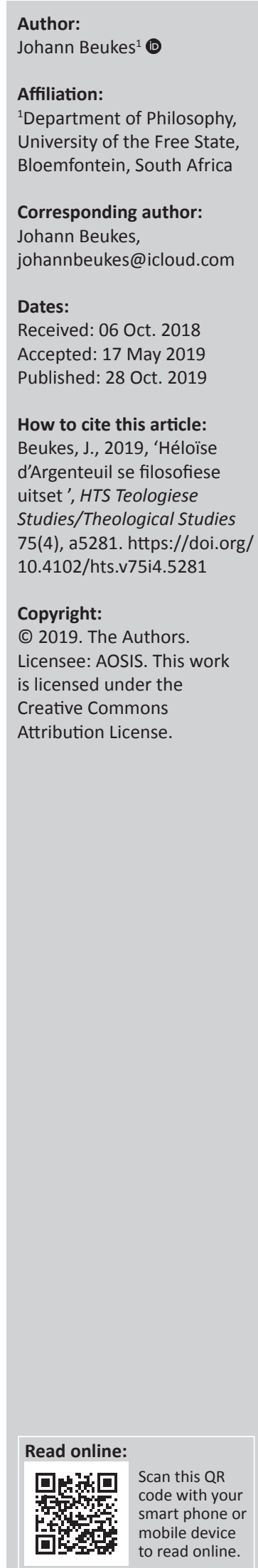

The philosophical output of Héloïse d'Argenteuil. This article attempts to deconstruct the overhyped erotic relationship between the philosopher-monk Peter Abelard (1079-1142) and philosopher-nun Héloïse d'Argenteuil (ca. 1100-1164), by surveying Héloïse's extant texts (Epistolae duorum amantium, Epistolae Heloissae and Problemata Heloissae) as such, isolating three themes in her philosophical output: her concept of Cicerian love, her criticism of marriage and her notion of moral and material responsibility, which includes her understanding of an ethics of attitude and intention. When Héloïse is read against the grain of the standardised Abelard-reception (which holds Héloïse as at best a productive correspondent of Abelard, yet a mere muse for his extensive academic output), she is brought into perspective as an independent thinker, who deserves more intellectual respect than to be caricaturised as either Abelard's secret young lover, or his unwilling wife. When her texts are read as independent outputs, albeit often in the form of correspondence, she steps forward as the 'first female philosopher of the Middle Ages'. Her relationship with Abelard, important as it was for both of them, is secondary to her standing as a philosopher proper.

Keywords: Epistolae duorum amantium; Epistolae Heloissae; Problemata Heloissae; Reception of Cicero; philosophy of love; material and moral responsibility; critique of marriage; an ethics of attitude and intention.

\section{Inleiding}

Hierdie artikel ${ }^{1}$ poog om die oorgepubliseerde, inderdaad karikatuuragtige erotiese verbintenis tussen die monnik-filosoof Petrus Abelardus (1079-1142) en filosoof-non Héloïse d'Argenteuil (ca. 1100-1164) te dekonstrueer, deur middel van 'n herwaarderende lesing van Héloïse se oorleefde tekste (Epistolae duorum amantium, Epistolae Heloissae en Problemata Heloissae) as sodanig. Drie temas word in Héloïse se filosofiese uitset aangedui, naamlik haar filosofie van liefde (vanuit haar resepsie van Cicero), haar opvatting van materiële en morele verantwoordelikheid (wat haar verstaan van 'n etiek van gesindheid en opset insluit) en haar kritiek van die huwelik as institusie.

Hierdie artikel argumenteer dekonstruerend dat Héloïse teen die grein van die gestandaardiseerde Abelardus-resepsie gelees moet word. Die Abelardus-resepsie dui Héloïse tradisioneel en sonder noemenswaardige uitsondering bloot as 'n produktiewe korrespondent van Abelardus en as ' $n$ muse vir sy buitengewone akademiese uitsette aan. Deur haar tekste egter te lees, vir wat dit is, vir wat daar staan, word Héloïse in perspektief gestel as 'n onafhanklike denker, wat meer verdien as om in die geskiedenis van die filosofie bloot as die jonger minnares en onwillige eggenote van een van die beroemdste Middeleeuse filosowe gekenmerk te word. Wanneer Héloïse se tekste as onafhanklike uitsette waardeer word, hoewel dikwels in korrespondensieformaat, tree sy as die eerste vroulike Middeleeuse filosoof na vore, met Hildegard van Bingen (1098-1179), Mechtild van Magdeburg (ca. 1207-ca. 1282), Hadewijch van Antwerpen (fl. 1240), Marguerite Porete (ca. 1250-1310) en Katharina van Siena (1347-1380) wat op haar spoor sou volg. ${ }^{2}$ Héloïse se verhouding met Abelardus, belangrik soos wat dit vir beide van hulle was, is na

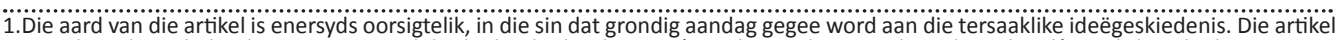
is andersyds ontledend en sintetiserend, bedoelende dat die primêre tekste gelees word sonder sekondêre teksbegeleiding, waarna die sekondêre literatuur geraadpleeg en getoets word aan die skrywer se aanvanklike lesing, om tot ' $n$ koherente byeenbring van die wesenlike kwessies in die Héloïse-nalatenskap te kom. Die betreklik vrye vertalings van Abelardus en Héloïse se tekste uit Latyn na Afrikaans, is die skrywer se eie.

2.Tullia van Aragona (ca. 1510-1556) en Moderate Fonte (1555-1592) val buite die skopus van die skrywer se datering van Middeleeuse filosofie (410-1464; vir'n wyer verantwoording van hierdie datering, sien Beukes 2011b:1):

Die post-Romeinse periode (vyfde tot sewende eeue [410 \{Alaricus I en die eerste barbaarse inval in Rome\} tot 668 \{d. Konstans II\}], met Augustinus [354-430] en Boethius [480-524] as die belangrikste filosofiese eksponente);

Die Karolingiese periode (agste tot negende eeue [742 \{g. Karel l\} tot 877 dd. Eriugena\}], met Alcuin [730-804] en Eriugena [815-877] as die belangrikste Latyns-Westerse geleiers van die Karolingiese Renaissance, met inbegrip van die opkoms van Arabiese filosofie in die Ooste en Andalusiese Spanje);

(2) 877 \{d Eriugena\} tot 1088 \{aanvang van die kruistogte en opkoms van die universiteitswese\}], met Anselmus [1033-1109] en Abelardus [1079-1142] as die mees gevolgryke onder die Latyns-Westerse denkers wat sou baat by die rehabilitering van die antieke erfenis in die Karolingiese Renaissance);
Die vroeg-skolastiese periode (11de tot 13de eeue [1088 \{stigting van die Universiteit van Bologna, die eerste Europese universiteit\} tot 1225 \{g. Aquinas\}]);

Note: Some parts of section 2 of of this article are based on work previously published by the author, Beukes, J., 2011, 'Die konstellasie taalbegrip-logika in die Middeleeuse filosofie (1): Augustinus tot Aquinas', HTS Teologiese Studies/ Theological Studies 67(3), Art. \#1072, 15 pages. http://dx.doi.org/10.4102/hts. v67i3.1072 
die diskursiewe aanspraak van hierdie artikel ondergeskik aan haar teenwoordigheid en aanspraak as 'n selfstandige filosoof.

Abelardus $^{3}$ is as die seun van 'n geslaande ridder in Le Pallet, Frankryk gebore. Hy het van jongs af skynbaar geen belangstelling in die praktiese quadrivium [wiskunde, meetkunde, astronomie en musiek] getoon nie, en hom tot die teoretiese lettere van die trivium [grammatika, retoriek en logika] beperk. In ongeveer 1100 is hy as student by Champeaux se katedraalskool by Notre Dame in Parys ingeskryf. Reeds as student was hy 'n versetlike leerling van Champeaux, veral met betrekking tot die vraag na universeles, binne die konteks van Roscellinus se nominalisme en Champeaux se realisme. ${ }^{4}$ Hy het die skool in 1103 verlaat en

(footnote 2 continues...) \{d. Ockham\}, met Aquinas, Duns Skotus en Ockham as die beroemdstes onder die hoog-skolastici]);

Die post-skolastiese periode (14de tot 15de eeue [1349 \{d. Ockham\} tot 1464 \{d. Kusa\}]).

3.Sien Abelardus $(1855,1919,1971)$ asook die volgende sekondêre tekste: BeonioBrocchieri Fumagalli (1969:1-12), Beukes (2011a:1-15, 2011b:7-10); Bosley en Tweedale (2006:296-303, 349-369); Brower \& Guilfoy (2006:1-12); Clanchy (1999:80-85); Compayré (1902:3-23); Copleston (1993:136-155); Grabmann (1957:168-228); Haren (1985:104-111); Hyman, Walsh \& Williams (2010:182-219); Iwakuma (2006:305-335); Kenny (2005:44-48); King (2006:65-125); Liebeschütz (1967:593-599); Luscombe (1970:1-13, 1971:xiii-xxx, 1988:279-307, 1992:127-138, 2004:47-56); Mann (2006:279-305); Marenbon (1988:135-163, 1997:7-16, 2006a:485-493 2006b:13-44); Martin (2006:158-199, 2010:129-145); McCabe (1972:1-15); McLaughlin \& Wheeler (2009:1-16); Mews (1986:73-134, 1995:7-16); Mews \& Jolivet (1990:105-140); Pinzani (2003:1-6); Smalley (1981:1-8); Spade (1994:26-56); Sweeney (2006a:1-7, 2006b:63-126); Tweedale (1976:1-15, 1982:143-158); Wadell (2008:1-25) en Wilks (2008:83-156).

4.Sien Champeaux (1993), asook die volgende sekondêre tekste: Copleston (1993:146-155); Grabmann (1957:136-141); Guilfoy (2012, in geheel); Haren (1985:90-92); Hyman, Walsh \& Williams (2010:182-219); I Iwakuma (1992:37-111 2006:307-309); Luscombe (2004:47-48); Marenbon (1988:135-163, 1992:51-61, 2006b:13-44, 2006c:690-691, 2010:129-450) en Tweedale (1988:196-226) 2006b:13-44, 2006c:690-691, 2010:129-450) en Tweedale (1988:196-226). wat reeds latent by Anselmus aanwesig was, in Champeaux se werk oopgedek sou word en direk deur sy Middeleeuse opvolger, Abelardus, polemies geadresseer sou word. Daarby is Champeaux se taalfilosofie en sy filosofiese teologie wel belangrik ten opsigte van die ontwikkelinge daarvan in die vroeg-skolastiek. 'Universeles' verwys na algemene begrippe wat gebruik word om 'n meervoud van individue aan te wys: byvoorbeeld, 'die mens', wat gebruik word om alle individuele mans, vroue en kinders aan te dui; of selfs nadere aanduidings soos 'blanke mans', wat gebruik word om mans aan te dui wat oënskynlik nie 'nie-blank' is. Die vraag is: wat beteken hierdie universeles in die verstand? Wat is die oorsprong daarvan in die verstand? Wat is die unveles in die ver wa verhouding tussen die universele noemer en die individue wat daardeur beskry word? Hierdie vrae en dergelike vrae is sonderling deur Plato, Aristoteles en Boethius beantwoord - en tog ook nie beslissend nie. Die vraag na die waarheidsaanspraak van universeles het 'notis binne di teologiese debat van die 11de eeu, aangeroer en as ' $\mathrm{n}$ probleem verhewig is. Roscellinus (ca.1050-1125), die hoof van di skool te Compiègne en later leermeester te Loches, wat Abelardus as leerling gehad het, se Triniteitsleer het die onderskeibaarheid van die drie Persone benadruk, ten koste van die opvatting van die Goddelike eenheid. Sy antwoord op die formeellogiese vraag wat die status van universeles is (in hierdie geval 'God'), was dat universeles bloot ' $n$ klank (flatus vocis) is. Die opvatting dat universeles bloot name of woorde is wat na niks partikulier of na geen partikuliere individu in die geleefde werklikheid verwys nie, staan as nominalisme bekend. By Roscellinus is dit egter meer as blote nominalisme: hy minimaliseer die betekenis van universeles so drasties hy kan, synde net ' $n$ klank met sy opvatting van flatus vocis. Dit sou 'n vokalistiese nominalisme genoem kon word en Roscellinus se navolgers is dikwels vocales of 'vokaliste' genom (luakuma 1992:38). Champeaux se posisie, met wat hy sou 'vokaliste' genoem (lwakuma 1992.38). Champeaux se posisie, met wat hy sou istiese teorieë van moontlik dat Champeaux 'n leerling van Roscellinus was, maar dit kon nog nie teenspraakvry in die navorsing bevestig word nie. Wat wel baie duidelik in die navorsing bevestig is, is dat Champeaux se eie leerling, Abelardus - wat soos bo genoem ook vir' $n$ tyd klas geloop het by Roscellinus - teen beide sy leermeersters se posisies sou agiteer. Trouens, naas die redaksiewerke van Iwakuma (Champeaux 1993; Iwakuma 1999), bestaan daar geen onafhanklike, selfstandige tekste van Champeaux nie. Wat ons oor Champeaux beskikbaar het, kom feitlik in geheel vanuit Abelardus se polemiese verwysings na en aanhalings vanuit Champeaux. Ons weet wel dat Champeaux onderrig gegee het by die katedraalskool in Parys en by die kloosterskool te St Viktor. Hy het ook, naas moontlik by Roscellinus, onderrig ontvan by 'die ander Anselmus' van die Middeleeue, Anselmus van Laon (d.1117), wat ter wille van onderskeid met Anselmus van Kantelberg normaalweg bloot 'Ansellus' of 'Ansel' ( geloofsartikels op geen wyse deur die rede bevat kon word nie en ook nie in gangbar ( begrond is. Champeaux se ultra-realisme beteken dat hy nie begin deur te vra ho die begrip klas (dit is, die meervoudigheid van individue binne die universele) me die bestaan van partikuliere individue korrespondeer nie, maar dat hy uitgaan van die na 'n paar jaar se omswerwinge as reisende dosent in filosofie, weer in 1114 by die katedraalskool by Notre Dame aangesluit as permanente dosent in filosofie.

Abelardus se biografie word normaalweg deur die oorgepubliseerde vyf jaar bepaal wat na 1114 gevolg het. Die waarheid is inderdaad altyd meer kompleks en meer aangrypend as fiksie. Abelardus en 'n privaat student Héloïse, meer as 20 jaar jonger as hy maar in alle opsigte sy geesgenoot, raak innig verlief. Sy was die niggie van die kanselier Fulbertius, uitvoerende hoof of canon van die Notre Dame Katedraal, wat in die Paryse samelewing van die vroeg-12de eeu 'n werklik eminente posisie beklee het. Na 'n jaar van intense seksuele ontmoetings, erotiese liefde en geesgenootskap, raak Héloïse swanger en die twee filosowe vlug weg van die skandaal wat daardeur by Notre Dame veroorsaak sou word, na die omstreke van Le Pallet, Abelardus se geboorteplek. Hulle beoog om daar op die platteland te bly, welwetend dat Abelardus daarmee van enige kerklike of akademiese bevordering ontneem sou word. Hulle beste pogings ten spyt, kom die verhouding en swangerskap egter tot Fulbertius se kennis. Hy dring aan dat hulle na Parys terugkeer, terwyl hy reëlings tref vir 'n geheime troue. Dit was egter net 'n listige plan om Héloïse met ongeskonde reputasie terug in sy huis en onder sy beheer te bring. Met die gevorderde swangerskap nou minstens familiekennis en beide se persoonlike en akademiese reputasies onder beleg, besef Abelardus dat hy as dosent by die katedraalskool moet bedank. Abelardus en Héloïse besluit daarna, hoewel op sy aandrang, dat sy hulle kind vir familie-aanneming sal opgee en dat beide as monnik en non tot die onderskeie kloosters te St Denis en Argenteuil in 1119 sou toetree. Met Fulbertius se bemiddeling, word Abelardus 'n tyd na die geheime huweliksluiting en kort na sy en Héloïse se toetrede tot die kloosters, in 'n donker kloostergang by St Denis wreed aangerand, tot die effek dat hy opsetlik ontman word. Die huwelik sou op Abelardus se aandrang nooit ontbind word nie, tot Héloïse se ontsteltenis. Vir haar vestig die filosofiese imperatief daarin dat sy nooit moes toegestem het tot die geheime troue, waarin Fulbertius (en Abelardus, by verstek) haar gedwing het nie.

Oor die volgende 23 jaar sou Abelardus en Héloïse in die geheim bly korrespondeer en mekaar net nog een keer van aangesig tot aangesig, by 'n kloosterseremonie in Parys in 1139 te siene kry. Drie jaar na daardie weersiens is Abelardus oorlede. Héloïse sou in die Parakleet-klooster oud word en is in 1164, 22 jaar na haar seksuele en intellektuele medeganger se afsterwe, as abdis van die Parakleet oorlede. Ses eeue later was Josephine Bonaparte so geroer deur die (in bostaande weergawe, inderdaad ware) verhaal van Abelardus en Héloïse, dat sy hulle grafte laat opgrawe het en hulle saam in die Pére Lachaise begraafplaas in Parys laat herbegrawe het. Die tombe word steeds jaarliks deur duisende belangstellendes besoek. ${ }^{5}$ Filosofies is dit egter belangrik dat beide Abelardus voorrang of prioriteit van die universele, en eers daarna die relevante individue definieer met verwysing na die universele.

5.Sien McLaughlin en Wheeler (2009:1-16) en Mews (2005:3-7). Die keurige estetiese aanbod en vertaling van Levitan (2007) kan ook geraadpleeg word. 
en Héloïse eers vanaf 1119, juis in mekaar se fisiese afwesigheid, maar steeds met innige tekstuele verbinding, as onafhanklike filosowe sou ontwikkel.

\section{'n Kort oorsig van Abelardus se filosofiese uitset}

Abelardus, naas Anselmus die belangrikste Latyns-Westerse filosoof in die post-Karolingiese periode, se kommentariërende werk vanuit die logica vetus het hom as 'n voorganger vir die volle herwinning van Aristoteles in die vroeg-skolastiek van die laat 12 de eeu en veral die hoog-skolastiek van die 13de eeu, en eerste helfte van die 14de eeu gevestig. Hierdie kommentariërende werk was histories gelyklopend met die toenemende aanbod van Latynse vertalings van die Arabiese vertalings van en kommentare oor die Aristoteliese en Neoplatoniese Griekse tekste. Abelardus se bydrae tot die Latyns-Westerse register, spesifiek as kommentator en interpreteerder van daardie ideëhistoriese tradisie, juis in die feitelike afwesigheid van 'n werkbare Aristoteliese korpus in Latyn op daardie stadium, kan trouens moeilik oorskat word. Die talle eietydse monografieë en kommentare wat oor Abelardus beskikbaar is, beklemtoon veral sy uitstaande bydraes in logika, etiek, metafisika en taalfilosofie, op grond van sy unieke nominalistiese en dialektiese posisies (sien Clanchy [1999:80-85], Marenbon [1997; 2006a; 2006b], asook Sweeney [2006b:63-126] en Wilks [2008:83-156;]. Gedateerd soos wat dit is, bly die inleiding van Compayré [1902:3-23] 'n tydlose bydrae tot die Abelardiese navorsing). Abelardus se tekstuele bydrae behels die volgende: sy dialektiek ('n byeenbring van logika, taalfilosofie en metafisika), geredigeer in sy twee invloedrykste werke, Logica Ingredientibus en Dialectica (die datering van Abelardus se tekste is al vir eeue 'n kontroversiële kwessie in die navorsing, omdat Abelardus tot en met sy dood sy eie werk konstant herredigeer en gedeeltes soms geheel oorgeskryf het. Dit het daartoe gelei dat verskeie uitgawes van 'n bepaalde werk in omloop was en steeds is [kyk ook McCabe 1972:54; Mews 1986:73-134]), met die vier kleiner werke in logika daaronder gegroepeer, naamlik Introductiones parvulorum, Logica nostrorum petitioni sociorum, Tractatus de intellectibus en Sententiae secundum Magistrum Petrum; sy etiek, opgeneem in Ethica seu Scito teipsum en sy kontroversiële dialoog tussen 'n Jood en 'n Christen, Collationes (later gesirkuleer as Dialogus inter Philosophum, Iudaeum et Christianum); sy filosofiese teologie, opgeneem in Theologia Summi Boni, Theologia Christiana en die laat Theologia Scholarium (vir 'n ontleding van die Megariaanse agtergrond van hierdie werk, sien Beukes 2011a).

Hierdie laaste drie werke is in die Abelardus-navorsing berug, omdat Abelardus in hierdie werke telkens poog om sy standpunte in aanvaarbare kerklike terminologie te herformuleer en sy posisie in die legendariese skermutseling met Bernardus van Clairveaux, rakende die talle aanklagte teen die beweerde ketterse kwaliteit van sy nominalisme, te bestendig. Abelardus gebruik die begrip dialektiek wanneer hy logika in gedagte het en die logica vetus as sodanig kommentarieer - vandaar die titel van sy beroemdste werk, Dialectica.

Abelardus staan in die tematiese verlengstuk van Augustinus en Boethius se posisies wanneer hy in die middelgedeelte van Dialectica postuleer: 'Logika is ars sermocinalis', dit is, 'n taalkundige dissipline (Abelardus 1971:148). Logika en taalbegrip kan op geen wyse van mekaar geskei word nie. Soos grammatika, bestryk logika woorde; maar dan juis betekenisstigtende woorde (sermones) en nie bloot klanke (voces) nie. Sy analise van sermones en sy wesenlike filosofiese bydraes val in die volgende vyf fasette uiteen.

Eerstens bepleit Abelardus 'n grammatikaal-logiese beweging vanaf eksistensiale proposisies na gekwantifiseerde proposisies. Dit doen Abelardus deur te beklemtoon dat 'n standhoudende logika met 'n uiteensetting van die grammatikale dele van spraak, veral met betrekking tot selfstandige naamwoorde en werkwoorde, moet begin. Aristoteles se posisie was natuurlik dat 'n onderskeid getref moet word tussen selfstandige naamwoorde en werkwoorde, omdat laasgenoemde altyd 'n tydsaanduiding bevat.

Let daarop dat die begrip dialektiek eers vanaf Abelardus die gangbare betekenis verkry het wat dit vandag nog het, naamlik van dialektiese redevoering as diskursiewe progressie aan die hand van die bewegingtese, antitese en sintese. Voor Abelardus het die begrip dialektiek bloot as 'n sinoniem vir die begrip logika gefunksioneer. Die begrip logika weer, het op die wyse gedui waarop die Middeleeuse denkers voor Abelardus Aristoteliese logika bestudeer en ontwikkel het, met die oog op die toepassing daarvan in veral teologie, deur middel van die 'ou logika'. In die Latynse Weste het hierdie 'ou logika', of logica vetus, uit die studie en toepassing van die tersaaklike elemente in die Aristoteliese Categoriae en De Interpretatione bestaan, asook die Neoplatonis Porhyreus se inleiding tot die Aristoteliese Organon. Die latere 'nuwe logika', of logica nova weer, het bestaan uit die studie en toepassing van die Aristoteliese Analytica Priora, Analytica Posteriora, die Topica en De Sophisticis Elenchis ('n aanhangsel van die Topica). Abelardus (1971:149) was vanuit die logica vetus van bogenoemde Aristoteliese posisie rondom die skeiding van selfstandige naamwoorde en werkwoorde bewus, en gee toe dat werkwoorde altyd tydsbepaald is, maar argumenteer dat ook selfstandige naamwoorde implisiete tydsaanduidings bevat. Subjekpredikate dui hoofsaaklik sake in die teenswoordige tyd aan: Sokrates was 'n seun' is logies slegs wanneer Sokrates se subjektiewe, teenswoordige toestand een van gevorderde leeftyd is. Indien tyd slegs in die werkwoord opgeneem sou wees, sou dieselfde stelling moes lui, "n seun was Sokrates', wat 'n valse stelling is. Die korrekte korresponderende sin sou moes lui, 'iets wat 'n seun was, is nou Sokrates'.

Hierdie voorbeeld illustreer die implisiete tydsaanduidings in selfstandige naamwoorde, wat ondersteun word deur 'n logies-toeganklike taalbegrip waar selfstandige 
naamwoorde met voornaamwoorde vervang word, gevolg deur beskrywende frases, byvoorbeeld 'die lig skyn in', wat logies herskryf sou kon word as 'iets wat lig is, skyn in'. Uitsluitend kenmerkend van werkwoorde is dus nie dat dit tydsbepaald is nie (want selfstandige naamwoorde is dit dus implisiet ook), maar dat werkwoorde sinskonstruksies moontlik maak. Sonder werkwoorde is daar geen sinne nie en ook geen sin in die sin van betekenis nie. Daar kan wel logiese sinne wees sonder selfstandige naamwoorde, soos by imperatiewe of eenvoudige indikatiewe ('kom hier!' of 'dit is koud'), maar geen sinne sonder werkwoorde nie (Abelardus 1971:149). Aristoteles se posisie was dat die gestandaardiseerde sinskonstruksie $s=p$ sou moes wees. Hoewel 'n sin soos 'Sokrates drink' nie die oorganklike copula $(=)$ bevat nie, argumenteer Aristoteles dat die sin altyd herskryf sou kon word as 'Sokrates is 'n drinker'. Abelardus (1971:138) argumenteer daarenteen dat die copula (=) 'n eenvoudige en verhelderende funksie verrig ten opsigte van 'n verbindingsfunksie wat reeds eksplisiet in elke werkwoord aanwesig is: '... is ' $n$ man' is reeds 'n eenheid, 'n enkelwerkwoord, dus 'is-'n-man'. Die werkwoord 'om te wees' of 'is' (est), word nie bloot gebruik as 'n verbinding tussen die subjek en predikaat nie, maar ook om 'bestaan' aan te dui. Abelardus beskou hierdie semantiese potensialiteit as wesenlik: est kan in 'n sin verskyn as verbonde aan 'n subjek (Socrates est) of as 'n derde element (Socrates est homo). In laasgenoemde geval dui est nie 'bestaan' aan nie en enige toegewing aan die aanspraak dat 'bestaan' wel deur est aangedui word, kan deur est homo ondermyn word as est-homo, as 'n eenheid, aan te dui. "n Vader bestaan' moet daarom nie verstaan word as sou "n vader' vir enige iets staan nie; die sin beteken eintlik 'iets is 'n vader'. 'Bestaan' val dan heeltemal weg as predikaat en word deur 'n kwantifiseerder en 'n werkwoord vervang. (Abelardus se logies-verantwoorde ontwikkeling deur grammatikaallogies vanaf eksistensiale proposisies na gekwantifiseerde proposisies te beweeg, is teologies uiteraard gevolgryk. Dit is trouens befaamd deur Russell [1945:437] beskryf as die enigste noemenswaardige teenvoeter vanuit die Middeleeue vir Anselmus se ontologiese argument vir God se bestaan. Dit het ook skerp nawerking geniet in onder andere die moderne logika van Gottlob Frege in die 19de eeu).

Naas die grammatikaal-logiese beweging vanaf eksistensiale proposisies na gekwantifiseerde proposisies, fokus Abelardus in Logica Ingredientibus (1919:20) tweedens op die probleem van universeles, wat inderdaad een van die sentrale filosofiese probleemstellinge in die hoog-skolastiek van die 13de eeu en eerste helfte van die 14de eeu sou word. Onoortuigd deur die uiteenlopende teoretiese posisies van beide sy leermeesters, die vokalistiese nominalis Roscellinus en die ultra-realis Champeaux, bepleit Abelardus (1919:25) 'n dialektiese middeweg tussen nominalisme en realisme. Enersyds beskou Abelardus die nominalistiese posisie as 'absurd': Om te beweer dat Johannes en Paulus niks in gemeen het buiten die naam of noemer, 'mens', nie, terwyl die noemer op elkeen betrekking het juis op sterkte van objektiewe ooreenkomste, is ' $n$ logies onhoudbare posisie.
Andersyds is dit ewe problematies om na die aanspraak van die realistiese posisie te beweer dat daar 'n substansieentititeit, in hierdie geval die species homo sapiens, is wat volledig in een en elke individu teenwoordig is. Dit sou beteken dat Johannes volledig identies aan Paulus is en op twee plekke gelyktydig sou moes wees. 'n Ooreenkoms tussen mense is nie iets substansieel of partikulier soos 'n mens nie, terwyl slegs 'n mens, oftewel individuele, partikuliere mense bestaan, soos Abelardus (1919) redeneer:

Wanneer ons byvoorbeeld beweer dat die ooreenkoms tussen mense nie self ' $n$ 'mens' is nie, moet ons dit vermy om voor te gee dat daar geen ooreenkoms is nie, omdat ons inderwaarheid wil beweer dat die een tog met die ander ooreenkom - en dit is uiteraard nie self weer 'n mens nie, maar ' $n$ 'status', 'n toepassing van die begrip mens op die partikuliere individu. (bl. 20)

Beide nominalisme en realisme val volgens Abelardus (1919:28) terug op 'n ontoereikende ontleding van wat dit beteken dat 'n woord 'beteken' of 'verwys'. Woorde verwys op twee wyses: woorde be-teken dinge en woorde ver-woord idees. Woorde be-teken dinge juis deur die gepaste idees konseptueel op te roep, daardie konsepte waarmee 'die verstand die dinge in die wêreld bring' (Abelardus 1919:32). Ons eien ons hierdie konsepte toe deur telkens verstandelike beelde te oorweeg, wat 'nie gewone beelde is nie' (Abelardus 1971:329). Dit is hierdie konseptuele oorweging van verstandelike beelde of fantasme wat ons in staat stel om woorde dinge te laat be-teken en wat klanke betekenisvolle woorde laat word. Daar is geen 'universele mens' los van die universele noemer 'mens' nie; nominalisme is korrek in daardie opsig. Maar die noemer 'mens' is ook nie sonder betekenis nie: dit word in die verstand verbeeld deur ons verstaan van die woord (vanuit die klank) 'mens'. Soos wat die beeldhouer 'n stuk graniet in 'n beeld vormeer, vormeer ons verbeeldende intellek 'n woord, vanuit 'n klank. Daarom is universeles 'intellektuele skeppinge, niks meer of minder nie' (Abelardus 1919:522). Of andersom: woorde be-teken universeles deurdat woorde universele konsepte tot uitdrukking bring. Maar woorde be-teken universeles nie op dieselfde wyse as wat woorde partikulieres in die wêreld be-teken nie. Daarom is daar inderdaad ' $n$ fundamentele grammatikale, logiese en epistemologiese verskil tussen universeles en partikulieres.

Daarom is dit ook nodig dat 'n onderskeid tussen wat 'n woord be-teken en waarvoor dit staan, getref moet word (Abelardus 1971:154). Die woord 'seun', byvoorbeeld waar en wanneer dit ook al in 'n sinskonstruksie voorkom, het dieselfde betekenis, naamlik ' $n$ jong manlike mens. Wanneer die woord 'seun' as subjek in 'n sinskonstruksie gebruik word soos 'Die seun hardloop skool toe', staan die woord 'seun' vir daardie spesifieke, partikuliere seun wat skool toe hardloop. Maar in 'n sinskonstruksie waar die woord 'seun' deel van die predikaat uitmaak soos 'Hierdie ou man was eens 'n seun', staan die woord vir niks. Met ander woorde, die woord 'seun' staan vir iets baie spesifieks in 'n baie spesifieke konteks, 'n partikulariteit, wat eenvoudig getoets kan word deur te vra: Watter seun? Dit is dus 'n logiese 
taalbegrip wat Abelardus se dialektiese posisie ten opsigte van universaliteit en partikulariteit steun.

Derdens bepleit Abelardus (1919:275; 1971:154) proposisiekritiek, 'n belangrike tematiese voorloper tot Albertus Magnus, Thomas Aquinas en die hoog-skolastiek van die 13de eeu en later se meer algemene diskoerskritiek. Ons moet hiervolgens nie net vra wat individuele woorde beteken nie, maar ook wat hele sinne, stellinge of proposisies beteken. Abelardus (1971:154) definieer 'n proposisie as 'enige verwysing wat waar of vals kan wees'. Ook hier het 'verwysing' 'n dialektiese, dubbele betekenis. 'n Ware proposisie verwys eerstens na 'n ware idee wat in woorde tot uitdrukking gebring word, en verwys tweedens na 'dit' wat inderdaad 'die geval' of 'die saak' is - wat Abelardus (1971:154) proponit id quod in re est noem. Dit is laasgenoemde wat vir formele logika van belang is - omdat die logikus op die betrokke stand van sake fokus wat logies vanuit 'n voorafgaande stand van sake vloei, eerder as die opeenvolging van mentale prosesse in die subjek se verstand. Die verheldering van die 'stand van sake' (rerum modus habendi se) deur die verwysingsdinamika van 'n proposisie, noem Abelardus (1919:275) die dictum van die proposisie. 'n Dictum is nie 'n feit of gegewe in die wêreld nie, omdat dit iets is wat waar of vals is, of kan wees. Die dictum is waar indien die relevante stand van sake in die wêreld self afgelei kan word, andersins is dit vals. Anders as talle ander Middeleeuse en ook sommige moderne logici, tref Abelardus dus duidelike onderskeid tussen 'n predikaat en 'n stelling. 'n Subjek en 'n predikaat mag saamgevoeg word, sonder dat enige stelling gemaak word. 'God het die mens lief' is 'n stelling, maar dieselfde subjek en predikaat word saamgevoeg in 'As God die mens liefhet, gaan die mens hemel toe' - sonder dat die stelling gemaak word (Abelardus 1971:160). Die logiese konsekwensie hiervan is dialekties-teologies natuurlik gevolgryk: 'n mens kan logies, koherent dog onsinnig oor die subjek 'God' en welke predikaat ook al praat, juis omdat geen stelling in die formeel-logiese sin van die woord gemaak word nie.

Vierdens definieer Abelardus (1919:506) logika as die 'kuns van die beoordeling en onderskeiding van geldige en ongeldige argumente'. Abelardus beperk argumente nie tot sillogismes soos in die ou logica vetus. Hy fokus op 'n ruimer en meer veralgemenende verstaan van die begrip, logiese konsekwensie, en gebruik ook nie Boethius se begrip, consequentia, wanneer hy logiese konsekwensie in gedagte het nie. Hy gebruik wel die begrip consequentia wanneer hy voorwaardelike proposisies in gedagte het: as $p$, dan $r$. Vir logiese konsekwensie gebruik Abelardus eerder die begrip consecutio, wat met 'oordrag' vertaal kan word. Natuurlik is die twee begrippe (consequentia en consecutio) nóú verwant, maar nie identies nie: wanneer 'as $p$, dan $r$ ' n logiese waarheid is, dan dra $p$ op $r$ oor, en $r$ volg vanuit $p$; maar 'as $p$, dan $r$ ' is dikwels waar sonder dat $p$ op $r$ oorgedra word. Vir $p$ om oor te dra op $r$ is dit natuurlik wesenlik dat 'as $p$, dan $r^{\prime}$ 'n noodwendige waarheid is, maar Abelardus wil daarmee verder gaan: 'As Sokrates 'n klip is, dan is Sokrates 'n esel', wat dan 'n noodwendige waarheid is - dit is onmoontlik vir
Sokrates om 'n klip te wees en juis so onmoontlik dat hy 'n klip sou moes wees sonder om ook 'n esel te wees (Abelardus 1971:293). Abelardus dring dus nie net daarop aan dat 'as $p$, dan $r$ ' 'n noodwendige waarheid moet wees nie, maar ook dat die noodwendigheid daarvan aan die inhoud van beide die antesedent en gevolg ontleen moet word: 'Daar moet 'n noodwendigheid van oordrag wees, naamlik dat wat bedoel word met die gevolg gedetermineer word, deur 'n verstaan van die antesedent' (Abelardus 1971:253). Maar die 'noodwendigheid van oordrag' vereis nie die bestaan van die dinge waaroor die antesedent en gevolg dit het nie: 'As $x$ 'n roos is, dan is $x$ 'n blom', bly noodwendig waar, 'ook al is daar geen rose meer in die wêreld nie' (Abelardus 1919:366). Dit is die dictum wat die oordrag dra, en die dictum is nie gedagtes of dinge in die wêreld soos rose nie

Laastens vestig Abelardus se bydrae in sy onderskeid tussen twee verskillende wyses waarop oor potensialiteit of moontlikheid gepraat sou kon word. ' 'n Proposisie soos 'Dit is moontlik vir die koning om nie koning te wees nie', kan so verstaan word: indien ons daaruit verstaan dat dit moontlik waar is dat die koning nie die koning is nie, is die proposisie duidelik vals (de sensu). Of ons sou daaruit kon verstaan dat die koning moontlik onttroon kan word, en dan is die proposisie inderdaad moontlik waar (de re). Die hoogskolastici sou later telkens na die teologiese gevolgrykheid van hierdie onderskeid terugkeer. In die tweede helfte van die 12de eeu is die volledige Organon of logiese korpus vanuit Aristoteles se oeuvre, na eeue se sistematisering en hervertalings vanuit die logica vetus en die ArabiesLatynse inwerking, met inbegrip van die wesenlike skarnierfunksie van Abelardus, beskikbaar gestel. Die Organon, gesupplementeer deur die Isagoge, die Boethiaanse weergawe van die logica vetus en die Abelardies-dialektiese taalbegrip-logika, tesame met 'n 12de eeuse anonieme werk, Liber de Sex Principiis, sou vir die volgende eeue die kern van die logiese kurrikulum aan die jong Europese universiteite vorm - nou as die logica novus - hoewel Abelardus se werk konstant gesubordineer is aan die Organon en eers in die latere Middeleeue weer skerper selfstandig sou begin funksioneer. In die eerste helfte van die 13de eeu het daar egter ook twee universiteitshandleidings ten aansien van die samehang tussen taalbegrip en logika verskyn, waarvan veral die tweede se invloed verreken moet word. Die eerste was die Introductiones in Logicam van die Oxoniaan Willem van Sherwood. Die tweede, minder bekend, was 'n reeks tekste, gebundel as die Tractatus, later gesirkuleer as Summulae Logicales, geskryf deur 'n latere Parysenaar, Petrus Hispanus, een van die mees ondergepubliseerde medewerkers tot die vroeg-skolastiek en die bestendiging van die logica novus.

Twee jaar voor sy afsterwe is aspekte van Abelardus se filosofiese uitset by die konsilie van Sens (1140), op grond van die polemiek met sy latere tydgenoot Bernardus van Clairveaux (1090-1153), veroordeel. Die spanning wat hierdie veroordeling by hom opgewek het, het sy afsterwe ongetwyfeld verhaas (Clanchy 1999:16). Hy is in daardie 


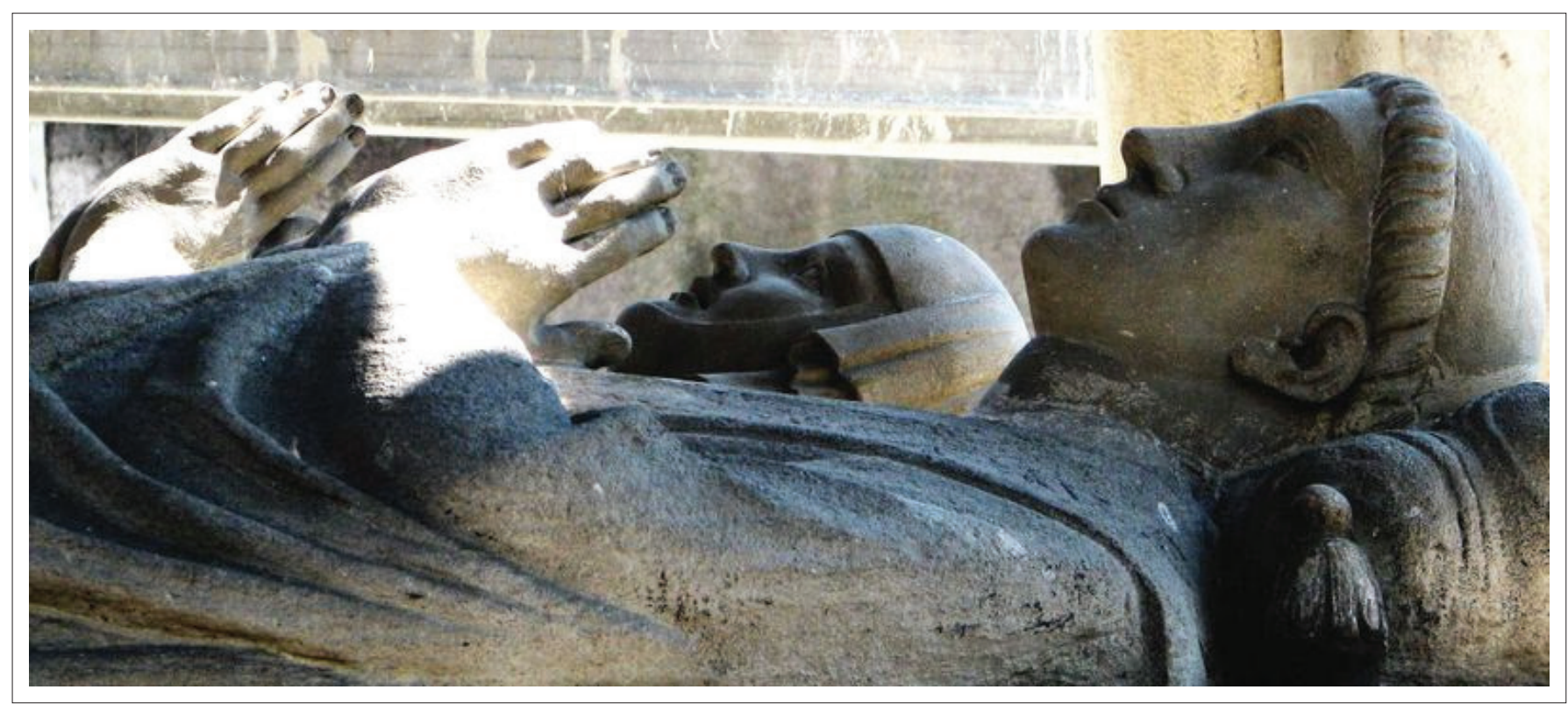

Bron: Interfoto. Abelard, Peter, 1079 - 21.4.1142, French philosopher and theologian, with his beloved Heloise, memorial slab, cemetery Père Lachaise, Paris, France, Additional-RightsClearances-NA

FIGUUR 1: Die tombe van Héloïse en Abelardus, Père Lachaise, Parys, Publieke domein.

opsig as 'n verbitterde intellektueel oorlede, maar het tot en met sy dood met Héloïse bly korrespondeer. Die spontane vraag is dan waarmee Héloïse self in hierdie jare vanaf 1119 tot 1164 in die kloosters te Argenteuil en die Parakleet besig was. Die antwoord is: met 'n oorspronklike en kritiese filosofiese uitset.

\section{Héloïse se tekste}

Héloïse sluit in $1119^{6}$ by die klooster in Argenteuil aan, nadat sy haar en Abelardus se baba (genaamd Astralabius) vir familie-aanneming oorhandig het (Figuur 1). Sy sou as non te Argenteuil en vanaf 1129 as abdis by die Parakleet, 'n klooster wat Abelardus self vroeg 12de eeu gestig het, tot en met haar afsterwe in 1164, woon en werk (McLaughlin 2000:3). Ons tref Héloïse se filosofiese uitset onder andere aan in die Epistolae duorum amantium, wat korrespondensie met Abelardus insluit, maar in filosofies-retoriese styl geskryf en aangebied is (Mews 2000:35). Sy is op grond van daardie teks ${ }^{7}$ sowel as die Epistolae Heloissae en Problemata Heloissae, die eerste van ses vroue wat tussen 410 en 1464 'n sodanig grondige teksspoor nagelaat het, sodat hulle genuanseerd as 'Middeleeuse filosowe' beskryf kan word.

6.Sien weer McLaughlin and Wheeler (2009:1-16), Levitan (2007) and Mews (2005:3-7) vir voortreflike inleidings tot die persoonlike verbintenis tussen Héloïse en Abelardus. Die eerste daadwerklik verkennende studie oor Héloïse se filosofiese betekenis is egter reeds in die 1930's onderneem deur die gevierde filosofiese betekenis is egter reeds in die 1930's onderneem deur die gevierde Middeleeuse navorser, Etienne Gilson (vertaling 1951). So verhelderend as wat
die bydraes in die onlangse redaksiewerk van Wheeler (2000) is, lewer geen bydrae daarin 'n daadwerklike korrektief op die baanbrekende tekste van Gilson (1951) en Dronke (1984) nie. Marenbon (2000) omlyn wel oop en bestaande nisse in die navorsing. Daarom word die bespreking hier grootliks ingerig met aansluiting by sowel Gilson as Dronke.

7.Hierdie bespreking is gebaseer op ' $n$ analise en sintese van die tekste van (D'Argenteuil) Héloïse (1855), asook die volgende sekondêre tekste: Brown \& Peiffer (2000:143-160); Clanchy (1999:80-85); Dronke (1984, in geheel); Georginna (2000:187-216); Gilson (1951, in geheel); Hamilton (1966:3-60); Luscombe (1970:1-13; 1971:xiii-xxx; 1988:279-307; 1992:127-138; 2004:47-56); Mann

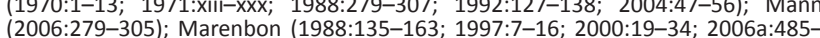
493; 2006b:13-44); Martin (2006:158-199; 2010:129-145); McCabe (1972:1-15); McLaughlin (2000:1-18); McLaughlin en Wheeler (2009:1-16); Mews (1986:73134; 1995:7-16; 2000:35-52); Waithe (1989:67-84) en Ward en Chiavaroli (2000:53-120).
Héloïse se filosofiese uitset was in terme van die oorspronklikheid daarvan vir eeue gekompromitteer deur juis haar verbintenis met Abelardus - vir baie lank het Héloïse as filosoof in haar medeganger se skadu vertoef. Haar werk is kwalik selfstandig en slegs met inbegrip van die korrespondensie tussen haar en Abelardus, onderskei.

Vanaf die laaste vyf dekades van die 20ste eeu, het die spesialisnavorsing egter toenemend aandag aan Héloïse se unieke filosofiese uitsette begin skenk, soos per oorsig in die redaksiewerk van Wheeler (2000) gereflekteer. Op grond van hierdie betreklik onlangse oorsigwerk, wat kommentaar op die ouer sekondêre tekste lewer, is dit moontlik om Héloïse as selfstandige denker toe te lig, met verwysing na haar Epistolae (korrespondensie met Abelardus en Petrus Venerabilis [ca.1092-1156]) en haar Problemata (bestaande uit 42 filosofies-teologiese probleme waaroor sy sistematies met Abelardus in gesprek getree het), asook die filosofies-etiese probleem rondom intensionaliteit, wat sy op 'n unieke wyse beredeneer het.

Voor Gilson (1951) se baanbrekende werk ten opsigte van die outeurskap van bogenoemde drie tekste, wat vandag teenspraakvry aan haar toegeskryf word, was daar altyd 'n vraag oor die outentisiteit van hierdie tekste. Hierdie outentisiteitsvraag kan toegeskryf word aan die (oorwegend moderne) opvatting dat geen vrou vanuit die 12 de eeu die intellektuele erudisie sou kon reflekteer, as wat in hierdie tekste aanwesig is nie - en dat die tekste deur Abelardus self of deur 'n latere monnik gefabriseer is. Dit is waar dat weinig vroue in die 12de eeu toegang tot sodanige intellektuele opvoeding gehad het - maar Héloïse en enkele ander vroue het wel. Sy het trouens akademiese erkenning ontvang nog voordat sy Abelardus sou ontmoet en sy privaatstudent sou word (Dronke 1984:111). Sy was 'n denker in eie reg en nie bloot die student van een van die beroemdste filosowe van sy tyd nie. 
Volgens Abelardus self (1855:33), kon Héloïse Latyn, Hebreeus en Grieks met die aanvang van sy privaatlesings aan haar, lees. Sy was dus in staat om die Latynse vertalings van Griekse en Romeinse filosofie, teologie, geskiedenis en letterkunde te bestudeer - en het grondig blyke daarvan gegee. Sy was formeel opgelei in retoriek - die tegniek om logiese argumente op 'n grammatikale basis te skoei (Marenbon 2000:485). Trouens, selfs net 'n oorhoofse lees van Héloïse se tekste dui 'n vertroudheid met teoretici soos Aristoteles, Ambrosius, Augustinus, Cicero en Aeschines Socraticus aan. In sy tegniese kommentaar en vertaling van die drie tekste, dui Gilson (1951:18) met kruisverwysings en 'n fyn, herlesende datering, dat Héloïse ongetwyfeld die skrywer van die Epistolae duorum amantium, Epistolae Heloissae en Problemata Heloissae was. ${ }^{8}$ Sedertdien is die outeurskap van hierdie drie tekste nog nie weer in die navorsing geproblematiseer nie, hoewel aspekte daarvan onder hersiening bly (Marenbon 2000:485).

\section{Héloïse se filosofiese uitset Ciceriaanse liefde}

Filosofiese temas wat selfstandig deur Héloïse hanteer word, sluit haar filosofie van liefde en vriendskap, haar nadenke oor materiële en morele verantwoordelikheid, en haar kritiek van sowel die huwelik as die kloosterwese in (Georgianna 2000:188). Gilson (1951:33) dui aan dat die filosofiese grondslae vir Héloïse se filosofie van liefde en vriendskap in Cicero se filosofie gegrond was. Die sentrale beginsel van Cicero se refleksie oor liefde is die gestrooptheid daarvan: 'Die vrug van liefde is liefde self' (Gilson 1951:49). Liefde het geen ander interesse as die liefde self nie. Liefde wil niks anders doen as om liefde te gee nie. Al wat die ware vriend vra, is om toegelaat te word om liefde aan die ware geliefde te bewys. Die liefde, vir Cicero, is radikaal onekonomies (Cicero 1914:xiv). Volgens Gilson (1951:53) is Héloïse se kritiek van die huwelik juis op hierdie Ciceriaanse beginsel geskoei: omdat die huwelik te make het met 'n ekonomie van belange, 'behoort ware geliefdes nie te trou nie' en eerder 'altyd onbaatsugtige vriende' te bly. Die liefde moet 'nie verteoretiseer' word nie, maar 'geleef word'; en dan, in 'n onvergeetlike idiosinkratiese uitspraak, 'die liefde moet altyd weer en opnuut die metafisies beste in die Ander tot uitdrukking bring'.

Gilson (1951:60) vind 'n merkwaardige refrein in Héloïse se korrespondensie met Abelardus: hoewel Abelardus voorgegee het om hierdie beginsel te onderskryf, het hy dit volgens Héloïse self inderwaarheid nie verstaan nie.

8.Gilson se ontleding is opgevolg deur Dronke (1984:56), wat met die Chi-wortel toets (in Engels: Chi-square, 'n filologiese en taalkundige analise van idiosinkrasieë in ' $n$ bepaalde skrywer se werk, met inbegrip van die sosio-historiese konteks van die skrywer) vasgestel het dat sowel Abelardus as Héloïse se korrespondensie stilistie verskil van ander 12de eeuse skrywers, onder andere Hildebertius, Salisbury, Silvestris, Venerabilis (met wie Héloïse self ook gekorrespondeer het) en Petrus de Blois. Beide Abelardus en Héloïse se styl vertoon wel 'n stilistiese voorkeur vir die essayistiese benadering van Adalbertus Samaratinus se Praecepta dictaminum essayistiese benadering van Adalbertus Samaratinus se Praecepta dictaminum (Waithe 1989:71). Tweedens het Dronke (1984:57) met 'n soortgelyke analise van die drie tekste (Epistolae duorum amantium, Epistolae Heloissae en Problemata Heloissae) teenspraakvry aangetoon dat Héloïse en Abelardus, afgesien van hierdi geneentheid tot Adalbertus se stilistiek, grondig van mekaar verskil in terme van woordaanbod, konseptuele voorkeure en argumentvoering. Héloise se styl word deur Dronke (1984:61) aangedui as 'logies-geartikuleerd' en 'selfbevestigend', anders as Abelardus se styl, wat as 'dialekties' en 'polemies' getipeer word.
Sy het in haar latere korrespondensie ál sterker blyke daarvan gegee dat Abelardus se karakter in hierdie opsig moreel verarmd was: hy het hom psigologies nie tot 'n morele oortuiging verbind, wat sy handelinge bepaal het nie. In Aristoteliese taal: die praktiese sillogisme is nie op die praktiese handeling oorgedra nie. Abelardus se toepassing van die Ciceriaanse beginsel van liefde en vriendskap, was dus suiwer teoreties. Hy het, volgens Héloïse self (Gilson 1951:61), nie besef of waargeneem dat sy verhouding met Héloïse juis die soort situasie geskep het waarin daardie beginsels (uit)geleef moes word nie. Abelardus was 'n man van die teoretiese rede, nie van die praktiese rede nie - terwyl Héloïse juis 'n denker van die praktiese rede was (sien Héloïse 1855:184).

Héloïse dui eksplisiet aan dat haar onwilligheid tot die huwelik met Abelardus, waartoe sy deur Fulbertius (en Abelardus) gedwing was, uit 'n filosofiese verset spruit, naamlik dat indien sy selfstandig tot so 'n huwelik sou toegetree het, dit nie sou strook met die Ciceriaanse beginsel van ‘belangeloosheid' nie (Gilson 1951:55).

Omdat sy hom belangeloos liefhet, het sy hom lief ter wille van 'die hoogste goed', wat in sy geval behels het die vervulling van die ideaal van outentieke filosoof-monnik te wees. Sy wil hom as vriend en medeganger bemin op 'n wyse wat, sy aanneem, sy oogmerk om 'n vervulde lewe volgens sy ideale (en nie haar ideale nie) te lei, ten beste sal volvoer. Vir haar beteken haar liefde vir Abelardus daarom 'n totale verwydering van Abelardus. Dit is op daardie grond dat sy die huwelik vir alle praktiese oorwegings versaak het, ingestem het om hulle kind vir aanneming op te gee en besluit het om as non tot die klooster te Argenteuil toe te tree. Daartoe was sy nie gedwing nie, hoewel dit wel Abelardus se dwingende wens was. Dit was vir haar die hoogste gebaar van liefde. Hulle intense seksuele verhouding en die gevolglike swangerskap was vir haar bewys dat die formulering van 'n morele oogmerk nie selfstandig genoegsaam is om 'n irrasionele hartstog te weerstaan nie. In daardie sin is beide sy en Abelardus 'gevallenes' of lapsi.

Waithe (1989:74) dui vanuit gesaghebbende eksegetiese navorsing aan dat Héloïse se aanvanklike heldeverering van Abelardus later in haar lewe omgeskakel het, na wat sy as 'n fundamentele karaktergebrek by hom waargeneem het, naamlik dat hy nie gehuiwer het om sy eie 'suiwer', teoretiesmorele opvattinge, op te offer, ter wille van seksuele gratifikasie nie. Abelardus, sou Héloöse later opmerk, was nie so gewillig om te doen wat hy self gepreek het nie. Sy is wel 'gevalle' in die sin dat sy toegelaat het dat seksuele hartstog tydelik oor die rede getriomfeer het - en gedink het dat Abelardus self toegelaat het dat seksuele hartstog slegs tydelik oor 'n morele ideaal sou triomfeer. Die feit dat Abelardus hom Fulbertius se aandrang op 'n geheime huwelik laat welgeval het, en sover gegaan het om die huweliksluiting van haar te verwag, dui egter daarop dat Abelardus permanensie aan die hartstog se oorwinning oor die rede en die morele ideaal wou gee, wat hom volgens haar 
'nog meer gevalle' maak. Sy gaan selfs sover (na Waithe 1989:74 se lesing) om Abelardus van skynheiligheid te beskuldig: om sy lewe volgens 'n bepaalde morele ideaal (in selibaat as filosoof-monnik) te lei, was vir hom uiteindelik nie so belangrik as om die indruk by ander te skep, dat hy sy lewe inderdaad volgens daardie ideaal lei nie. Hy het hom Fulbertius se aandrang op 'n geheime troue laat welgeval, sodat hy steeds seksuele toegang tot haar kon geniet en sy, in terme van die sakrament van die huwelik, 'n seksuele verhouding met hom moes handhaaf - selfs nadat beide tot hulle onderskeie kloosters toegetree het en Abelardus steeds die indruk van die morele ideaal van selibaatskap in die openbare lewe gelaat het. Hulle is in die geheim getroud niemand buiten Fulbertius het van die huwelik kennis gedra nie. In plaas daarvan om die huwelik in die geheim te ontbind, het Abelardus op die handhawing van die huwelik aangedring. Fulbertius het die voortsetting van die seksuele aspek van die huwelik, tussen 'n nou geordineerde monnik en 'n geordineerde non, as onheilig bestempel en dit was op daardie gronde dat hy sorg getref het dat Abelardus ontman sou word.

Volgens Fulbertius, in sy erkenning teenoor Héloïse van sy deurslaggewende aandeel in Abelardus se verminking, was dit die enigste manier om Abelardus se vergryp aan die jonger vrou, te stuit.

Héloïse (1855:184) se kritiese reaksie was dat Abelardus haar nooit liefgehad het soos sy hom liefgehad het nie.

Sy het hom liefgehad ter wille van hom, ongeag die prysgawe wat dit vir haar moes meebring - terwyl hy haar liefgehad ter wille van seksuele toegang, selfs as geordineerde monnik, en haar nie liefgehad het ter wille van haar nie. Sy was teen die huwelik gekant, omdat nie een van hulle daarby sou baat nie. 'n Huwelik sou, vanuit haar Ciceriaanse opvatting van liefde, Abelardus kompromitteer om 'n lewe volgens die morele ideaal van 'n selibate filosoof-monnik te lei. 'n Huwelik sou haar kompromitteer, in die sin dat dit die indruk sou skep dat sy haar deur Abelardus laat verlei het, ten einde die materiële voordele wat 'n huwelik sou meebring, in beskerming te kon neem. Sy dring daarop aan dat sy haar nie 'laat verlei' het nie, maar dat die periode van intense seksuele interaksie tussen haar en Abelardus, vanaf minstens 1117 tot 1119, een van wilsooreenstemming tussen beide partye was, waarin seksuele hartstog slegs tydelik toegelaat is om oor ' $n$ hoë morele en rasionele ideaal te seëvier. Gilson (1951) merk op:

Vanaf die oomblik dat sy Abelardus se vrou geword het, was Héloïse nooit weer seker of sy nie meegewerk het tot Abelardus se morele gevallenheid nie. Sy moes haar nooit die huwelik laat indwing het nie. Dit is die drama van Hélö̈se (bl. 47)

Héloïse (1855:186) beskryf Abelardus as 'gedetermineerd' om die seksuele verhouding met haar voort te sit. Vir hom was die vraag bloot kontekstueel: sou dit binne 'n geheimsinnige, nooit-ontbinde huwelik wees, of heeltemal buite die huwelik? Voor sy kastrasie, het Abelardus op geen stadium teenoor haar blyke gegee dat hy die selibaat as morele ideaal onderskryf het nie - hoewel hy moeite gedoen het om die indruk te skep dat hy die selibaat wel onderskryf. Hy wou slegs erken word as iemand wat die ideaal van die selibaat leef, maar wou dit nie werklik self leef nie. Daarom was sy gekant teen die geheime huwelik: sy wou Abelardus help om die morele ideaal, wat hy skynbaar verloor het, te herwin. Sy het hom in daardie sin Ciceriaans, belangeloos, liefgehad. Sy wou hom help om sy ware wil, wat die rasionele wil is, te herspoor en te herleef, eerder as die verdwaalde, passiegedrewe wil, wat hy teenoor haar openbaar het, maar in die openbaar versluier het. Héloïse wou aanvanklik niks te make hê met Abelardus se 'versaking van sy ideaal nie'. Sy gee toe dat sy daardie versaking kon veroorsaak het, in die sin dat sy die passie kon veroorsaak het - maar sy weier om toe te gee dat sy moreel verantwoordelik daarvoor was. Dit was Abelardus se keuse. Indien sy hom regtig liefhet, moes sy hom help om terug te vind 'wie hy werklik is'. Sy skryf (1855:181) dat sy Abelardus gesoebat het om nie te trou nie want deur haar te dwing om met hom te trou, sou sy Abelardus se morele vryval legitimeer. En tog is dit presies waarop hy aangedring het.

In haar tweede brief aan Abelardus (Héloïse 1855:186), skryf Héloïse oor 'n belangrike toegewing wat sy gemaak het rakende Abelardus se versaking van sy morele ideaal, nog voor die geheime huweliksluiting.

Abelardus se skynbaar onkritiese houding teenoor die triomf van die passie oor die rede, sou volgens haar op daardie stadium nog herstel kon word. Hy kon steeds kies vir algehele kuisheid vorentoe en om dit wat agter is, agter te laat. Dit sou hy kon doen om self te weier om aan die gedwonge, geheime huweliksluiting mee te doen en sy morele ideaal opnuut te prioretiseer. Deur egter te weier om sy morele ideaal die laaste woord te gee, het hy haar gedwing om te sondig - en meer, hy het haar gedwing om 'n 'misdaad teen hom te pleeg', omdat sy selfs bereid was om sy buiteegtelike minnares te wees, eerder as sy vrou. Sy wou juis uit liefde nie trou nie - hy wou, by gebrek aan ware liefde vir haar en nie ter wille van haar nie, steeds trou. Hy wou trou ter wille van hom. Toe Abelardus in 1119 aandring dat beide van hulle tot die kloosterwese toetree - met die geheime huwelik steeds onontbind - het sy gehoop dat hy uiteindelik ingesien het dat die selibaat die enigste sleutel vir die herstel van sy morele ideaal sou kon wees.

Tog het hy hom seksueel aan haar bly opdring, selfs tot net voordat hy deur Fulbertius se handlangers ontman sou word. En vir Héloïse bly dit die bitterste pil om te sluk: na die kastrasie het Abelardus skynbaar alle belangstelling in haar verloor. Enersyds voel sy verantwoordelik vir die kastrasie - indien sy nie toegegee het aan die druk om geheimsinnig met Abelardus in die huwelik te tree nie, en eenvoudig alle kontak met hom verbreek het, sou Fulbertius Abelardus nog gespaar het. Maar juis omdat sy vanuit liefde by Abelardus betrokke wou bly, ter wille van Abelardus, het Fulbertius tot daardie laaste verskriklike daad oorgegaan: 
Die verskriklike straf wat jou aangedoen is, sou nog kon deug as weerwraak vir mans wat betrokke was by openlike owerspel. Maar wat ander sou toekom vir owerspel, het jou oorgekom op grond van 'n huwelik wat nooit moes wees nie. Dalk het jy gedink dat die huwelik al ons verkeerde besluite sou herstel ... wat owerspelige vroue hulle minnaars laat oorkom, het jou eie vrou jou laat oorkom ... Jy alleen is gestraf, hoewel beide van ons die blaam moet dra. (Héloïse 1855:187)

Sy volg dit egter meer berekend op met die gevolge van die gewraakte kastrasie: eens ontman, was 'n voortgaande, uitsluitlik seksuele verbintenis, onmoontlik. Daarom gee Abelardus blyke daarvan dat hy haar nie langer liefhet nie. Die liefde wat in haar voortgeleef het, was in Abelardus se hart net tydelik. Seksuele passie het in Abelardus die gesag bo die Ciceriaanse liefde gevoer, wat vir haar permanent is. Hy het haar nooit liefgehad buite die konteks van sy eie passie nie. Héloïse sou, by insig in daardie werklikheid, nooit herstel van die verlies aan Abelardus nie - nie as man, minnaar of mede-kloosterling nie, maar juis as haar medeganger in Ciceriaanse liefde. Sy het liefde bo die huwelik gekies. Hy het 'n geheime huwelik, met die dwingelandy daarin aanwesig, bo die liefde gekies.

\section{Kritiek van die huwelik as institusie}

Die ironie van dit alles is dat Abelardus ' $n$ uitgebreide geskrif rakende die morele oogmerke van die Ciceriaanse opvatting van liefde die lig laat sien het, as naamlik suiwer, belangelose liefde (Scito te ipsum; Abelardus 1855:640B). Volgens Abelardus vestig die morele waarde of inhoud van 'n handeling in die oogmerk daarvan, of die opset daartoe. 'n Mens kan dus op 'n wyse handel wat moreel afwysbaar is, maar is nie sonder meer moreel verantwoordelik vir die handeling nie, of 'n mens kan skuldig wees aan die oortreding van ' $n$ wet, maar sonder dat 'n mens die opset gehad het om die wet te oortree. Insgelyks kan 'n mens sondig deur bloot die opset om te sondig, te vorm - of die opset uiteindelik fisies gestalte aanneem, of nie. Dit is die posisie wat Héloïse handhaaf: sy het aandeel daarin gehad dat teenspoed en ongeluk Abelardus sou oorkom (op vele wyses, volgens haar eie toegewings: deur passie in hom op te wek, deur hom te verlei, deur onder druk te swig en met hom in die geheim te trou, deur Fulbertius 'n rede te gee om hom te laat ontman), maar sy is nie skuldig nie. Sy het gesondig, maar is nie verantwoordelik nie. Trouens, volgens Abelardus (1855) self:

in die geval van 'n bose daad, berus die regmakende herstel nie op die effek van die daad nie, maar op die gesindheid van die agent; nie op wat gedoen is nie, maar met watter gesindheid dit gedoen is. (bl. 640B)

Héloïse was verpletter deur die besef dat hierdie teoretiese posisie, wat sy by Abelardus geleer en van hom oorgeneem het, nie sy eie gesindheid teenoor haar bepaal het nie; trouens, 'sy kan die begrip "onskuldig" nie op Abelardus van toepassing maak nie' (Héloïse 1855:185). Sy kan haar eie handeling en haar eie intensie van mekaar onderskei en as moreel nie-verantwoordelik staande bly. Maar Abelardus kan nie. In Epistolae Heloissae (II; 1855:186) skryf sy dat Abelardus nooit die 'goeie gesindheid' teenoor haar geopenbaar het as wat sy teen hom geopenbaar het en wat trouens elke aspek van haar optrede teenoor hom, bepaal het nie.

Toe sy 'n gedwonge huwelik wou weier op grond van die beginsel van belangelose vriendskap, het hy ' $n$ verbintenis vanuit seksuele impulse nagejaag. Waar sy uiteindelik bereid was om tot die klooster toe te tree, sodat hy 'n selibate lewe kon voer om sy morele ideaal te herspoor, het hy hom toenemend van haar onttrek.

Waar sy dieselfde selflose liefde na sy kastrasie getoon het as daarvoor, het hy belangstelling verloor toe die moontlikheid van die gratifikasie van seksuele begeerte opgehef is. Héloïse (1855:187) dui aan dat Abelardus se handelinge by elke kruispad gekorrespondeer het met die morele inhoudloosheid van sy opset. Sy konkludeer dat Abelardus se optrede teenoor haar gegrond was in mag, posisie en plesier - en nie in die opset tot ' $n$ morele ideaal waaroor hy hoog in die openbaar opgegee het nie. Wanneer sy in die middel 1130's oor haar en Abelardus se verbintenis besin, beskou sy Abelardus op grond van hierdie verhouding tussen materiële en morele verantwoordelikheid, as moreel aanspreeklik - en nie bloot materieel verantwoordelik nie. Sy self, aan die ander kant, was materieel aanspreeklik, maar nie moreel verantwoordelik nie.

Gilson (1951:49) se lesing van Héloïse se tekste maak dit duidelik dat sy die waardigheid van 'n monnik of non, juis as filosoof, neweskikkend tot selfbeheersing stel. Abelardus se posisie was dat hy in die geheim met Héloïse getroud kon bly, wat die uitwendige fasade van selfbeheersing kon waarborg, terwyl hy private seksuele toegang tot haar kon bly geniet. Héloïse se posisie was anders: juis ter wille van filosofiese waardigheid, selfbeheersing en Ciceriaanse liefde, moes hulle nooit getrou het nie en moes hulle inderdaad geen persoonlike verbintenis bly handhaaf het nie. Gilson (1951) verduidelik as volg:

Sy was nie tevrede dat Abelardus bloot die aura van grootsheid sou uitstraal nie, sy wou dat hy daadwerklik groots moes wees ... vandaar haar direkte argumente en die beslissende gevolgtrekkings waartoe sy gekom het. Deur die huwelik het Abelardus 'n permanent gevalle monnik geword, wat andersins 'n tydelike posisie sou wees. Natuurlik, eers getroud, sou hulle liefde moreel en godsdienstig legitiem wees ... maar beoordeel vanuit die morele ideaal van die monnik-filosoof, sou hulle lewens net so bevlek wees as altyd vantevore; trouens, nou sou hulle lewens onherroeplik as onsuiwer bevestig wees. (p. 5)

Dit is presies wat Héloïse wou verhoed.

Maar sy was ook prakties. Abelardus was ongetwyfeld altyd en in die eerste plek ' $n$ filosoof. En filosowe hoort in die wêreld, 'nie by die huis nie' (Hamilton 1966:42). Reeds in 1117, met die seksuele aspek van hulle verbintenis op 'n hoogtepunt, pleit Héloïse by Abelardus om 'in die wêreld' te wees. Sy voeg daarby dat indien hulle ooit sou trou, dit sy 
opgang in die kerk self aan bande sou lê: hy sou vernaamlik nooit as priester georden kon word nie. Hy sou onder geen omstandighede in die katedraalskool by Notre Dame vir bevordering in aanmerking gebring kon word, sonder priesterlike ordinasie nie. Dit is in elk geval waar sy hom sien: 'My een, my filosoof, binne die kerk' (Héloïse 1855:186). Om haar pleidooi te sterk, beroep sy haar op Paulus, Hieronimus en nogeens Cicero. Sy pleit, in 'n uitstaande blyke van Ciceriaanse liefde, by Abelardus om eerder 'toegelaat te word om sy prostituut as om ooit sy vrou te wees' (Hamilton 1996:42). Toe reeds, meer as 'n jaar voor Fulbertius se ingrepe rondom 'n geheime huwelik, het Abelardus geweier. En toe reeds voel Héloïse die dreigende tragedie aan: 'Dit is baie seker dat ons vernietig sal word; ons hartseer sal net gemeet kan word aan die intensiteit van die seksuele liefde wat ons eens gehad het' (Héloïse in Hamilton 1966:42).

Bykans 20 jaar later, in die middel van 1130, ontvang Héloïse, toe as abdis van die Parakleet, 'n kopie van Abelardus se Historia Calamitarum, waarin hy die sakramente, onder andere die huwelik as sakrament, met 'n mate van selftevrede outoriteit, bespreek. Abelardus gebruik, met erkenning, heelwat van Héloïse se kritiese perspektiewe teen die huwelik, vanuit haar Ciceriaanse oriëntasie. Tog maak Abelardus hom skuldig aan bewustelike weglatings uit die korrespondensie. Hy laat byvoorbeeld uit dat Héloïse 'liefde bo die huwelik' en 'vryheid bo ' $\mathrm{n}$ band' stel (Hamilton 1966:71). In haar antwoord op hierdie en ander weglatings, reageer Héloïse (1855:190) - en nou vanuit die respektabele posisie as abdis van die Parakleet - dat haar standpunt hieroor nie verander het nie. Indien sy die geleentheid gehad het om weer te kies, sou sy altyd steeds téén die huwelik gekies het - ter wille van vrye liefde (in die Ciceriaanse sin). Sy gaan weer so ver om selfs prostitusie bo die huwelik te stel - omdat die huwelik radikaal teen wat goed is vir Abelardus, indruis. Sy stel weer, en sy bedoel dit uiteraard hiperbolies, dat sy ter wille van Abelardus, 'eerder sy prostituut as sy vrou wou wees'. Sy bevestig dat die huwelik Abelardus sou bind, verblind en begrens, met verwysing na sowel sy persoon as akademiese loopbaan. Sy bevestig: sy het hom altyd liefgehad vir hom. Die goeie sou vir hom op geen wyse in die huwelik kon manifesteer nie.

Tog eerbiedig Héloïse terselfdertyd die huwelik as sakrament. Gekant teen en krities soos wat sy is oor die huwelik, behoort die volgens haar 'normale prerogatiewe' hulle gang te gaan, wanneer die huwelik eers gesluit is. Sy skryf aan Abelardus dat sy die huwelik respekteer - maar nie sonder voorbehoude, hulle huwelik nie. Tog het sy, vanuit hulle 'huwelik' (en sy benadruk dat sy eerder onder druk toegegee het aan hierdie huwelik eerder as om daartoe in te stem), haar 'pligte as 'n Christelike vrou', nagekom (1855:192). Sy het immers die baba op sy aandrang vir aanneming oorhandig. Sy het op sy aandrang tot die kloosterwese toegetree. Sy het later vanaf Argenteuil na die Parakleet oorgegaan, op sy aandrang (vanuit selfs net hulle korrespondensie). Sy het die Parakleet hervorm en opgebou op sy aandrang, as 'n veilige hawe vir nonne, 'vir mense soos ons'. Sy het deurgaans sy wil en sy besluite eerbiedig. Maar sy het hom ook herinner aan sy verantwoordelikhede teenoor haar, aangesien sy dan nou teen wil en dank wel sy eggenote is: sy is geregtig op liefde en respek; en as abdis van die klooster wat hy self jare vantevore gestig het, is sy geregtig op sy billike leiding en advies. Allermins is dit aansprake wat 'n prostituut sou maak. En tog is dit wat Abelardus nie doen nie - trouens, in sekere sin behandel hy haar soos 'n prostituut. Hy skryf steeds ad hoc, sporadiese liefdesgedigte aan haar en deel aspekte van sy intellektuele werk met haar - maar sy ontvang geen uitdruklike, konkrete en openbare ondersteuning van hom nie. Sy bevestig dan dat Abelardus drasties mank gaan aan 'n begrip van Ciceriaanse liefde:

... hy het homself op geen stadium verbind tot die welsyn van Héloïse nie; hy, wat nie net die stigter van die Parakleet was nie, maar haar eggenoot, moes stappe geneem het om haar te help in die lewe wat sy by hierdie orde gelei het ... dat hy dit nie gedoen het nie, was in haar oë 'n growwe gebrek en mistasting. (Hamilton 1966:74)

\section{Morele en materiële verantwoordelikheid}

Dit is op grond van hierdie 'growwe gebrek en mistasting' dat Héloïse in die laaste gedeelte van die Problemata nogeens die temas van 'n filosofie van liefde en daaruit, materiële en morele verantwoordelikheid, bespreek. Sy vra (1855:196) weer of dit moontlik is om te sondig binne die konteks van iets wat toelaatbaar is, of wat selfs 'n gebod van God is. Is dit moontlik om byvoorbeeld seksueel in die huwelik te sondig? Sy beantwoord die vraag bewustelik met verwysing na Abelardus se etiek van opset: aangesien dit die opset, en nie die handeling self is wat sondig is nie, herondersoek Héloïse beide haar eie en Abelardus se opset in hulle 'deelname aan die sakrament van die heilige huwelik'. Sy konkludeer dat beide van hulle 'kaal, arm en gestroop voor die sakrament staan': Sy het nooit die opset gevorm om selfstandig tot die huwelik toe te tree nie, maar het vanuit onskuld en 'swak wil' gedoen wat verkeerd is: daarmee bedoel sy juis nié die seksuele verhouding met Abelardus nie, maar haar toegewing aan die huwelik wat daarna op haar afgedwing is. Abelardus, aan die ander kant, is skynbaar selfs nie 'eens versoek' nie: hy het van meet af aan sonder enige voorbehoud een opset gehad, en dit was om Héloïse as 'n seksueel-toeganklike medeganger vir hom in te palm, terwyl hy slegs die persepsie van 'n selibate monnik na buite voorgehou het, met net een bykomende opset, en dit was om sy loopbaan te bevorder. Die huwelik was net 'n sleutel tot hierdie opset, niks meer nie (Gilson 1951:62). Abelardus het op geen stadium die psigologiese skade wat die angs aan hierdie verbintenis vir Héloïse sou meebring - en die wrede, brutale gevolge daarvan vir homself - oorweeg nie. Vir Héloïse was dit juis die kommer oor die gevare wat die verbintenis vir Abelardus ingehou het, sy welsyn, wat die swaarste geweeg het. Vir haar was Abelardus se hoogste goed die hoogste goed. Héloïse (1855:197) noem dit 'geestelike kuisheid': die volledige toewyding van twee mense vanuit selflose, belangelose liefde, waartoe 'n 'wettige huwelik' geen bydrae kan lewer 
nie en wat gebaseer is op ' $n$ wedersydse en gelyklopende Ciceriaanse opset, naamlik om die metafisies beste in die Ander na vore te bring, juis ten koste van die Self. Beide Abelardus en Héloïse het hierdie beginsel teoreties onderskryf, maar net Héloïse het dit konkreet uitgeleef. Abelardus was die mees briljante filosoof van sy tyd, maar kon nie die basiese beginsels wat hy Héloïse geleer het, en veral by haar geleer het, vorentoe neem en eksistensieel bestendig nie.

Nietemin, met inbegrip van haar skerp kritiese reaksie teen en progressiewe ontnugtering met Abelardus as mens en as man, het Héloïse haar emosioneel nooit van hom losgemaak nie. Dit is daarom mistastend om geromantiseerd van die liefde tussen Abelardus en Héloïse te praat. Allermins: dit is eerder die liefde van Héloïse wat bly talm. Sy was een van die mees opgevoede en intellektueel-afgeronde vroue van haar tyd. Haar korrespondensie met Abelardus en die tekste wat daaruit ontstaan het, dui nie op 'n minderwaardige vrou, selfs in die vrou-afwysende $12 \mathrm{de}$ eeu, nie. Ons ontmoet Héloïse in haar artikulering van 'n Ciceriaanse filosofie van liefde, eerder 'n buitengewone mens, 'n skrander denker en die deugdelikste van nonne. Sy was nooit Héloïse Abelardus nie. Sy is Héloïse d'Argenteuil.

\section{Erkenning \\ Mededingende belange}

Die outeur verklaar dat hy geen finansiële of persoonlike verbintenis het met enige party wat hom nadelig kon beïnvloed in die skryf van hierdie artikel nie.

\section{Outeursbydrae}

J.B. was die enigeste outeur betrokke by die skryf van die artikel.

\section{Etiese oorwegings}

Hierdie artikel volg alle etiese standaarde vir navorsing.

\section{Befondsing}

Hierdie navorsing het geen spesifieke toekenning ontvang van enige befondsingsagentskap in die openbare, kommersiële of nie-winsgewende sektore.

\section{Data beskikbaarheidsverklaring}

Data-deling is nie van toepassing op hierdie artikel nie, aangesien geen nuwe data in hierdie studie geskep of ontleed is nie.

\section{Vrywaring}

Die sienings en menings wat in hierdie artikel uitgedruk word, is dié van die outeur (s) en weerspieël nie noodwendig die amptelike beleid of posisie van enige geaffilieerde agentskap van die outeurs nie.

\section{Literatuurverwysings}

Abelardus, P., 1855, Patrologia Latina 178, in J.-P. Migne (ed.), viewed 17 September 2018, from http://patristica.net/latina.

Abelardus, P., 1919, Logica: Logica ingredientibus et Logica Nostrorum Petitioni, Beiträge zur Geschichte der Philosophie des Mittelalters, p. 15, Aschendorff, Münster.

Abelardus, P., 1971, Dialectica, in L.M. De Rijk (ed.), Van Gorcum, Assen.

Beonio-Brocchieri Fumagalli, M.T., 1969, The logic of Abelard, D. Reidel, Dordrecht.

Beukes, J., 2011a, 'God kan net doen wat God wel doen: Petrus Abelardus se Megariaanse argument in Theologia Scholarium, Opera Theologia III', HTS Teologiese Studies/Theological Studies 67(1), Art.\#124, 1-15. https://doi.org/ 10.4102/hts.v67i1.883

Beukes, J., 2011b, 'Die konstellasie taalbegrip-logika in die Middeleeuse filosofie (1) Augustinus tot Aquinas', HTS Teologiese Studies/Theological Studies 67(3), Art.\#1072. https://doi.org/10.4102/hts.v67i3.1072

Bosley, R.N. \& Tweedale, M.M. (eds.), 2006, Basic issues in Medieval philosophy: Selected readings presenting the interactive discourses among the major figures, Broadview Press, Toronto.

Brower, J. \& Guilfoy, K., 2006a, 'Introduction', in J. Brower \& K. Guilfoy (eds.), The Cambridge companion to Abelard, pp. 1-12, Cambridge University Press, Cambridge.

Brower, J. \& Guilfoy, K. (eds.), 2006b, The Cambridge companion to Abelard, Cambridge University Press, Cambridge.

Brown, P.R. \& Peiffer, J.C., 2000, 'Heloise, dialectic and the Heroides', in B. Wheeler (ed.), Listening to Heloise: The voice of a twelfth-century woman, pp. 143-160, Palgrave Macmillan, New York.

Champeaux, W., 1993, 'Introductiones dialecticae secundum Wilgelmum \& Secundum G Paganellum', in Y. Iwakuma (ed.), Cahiers de 'I Institur du Moyen-age Grec et Latin vol. 63, pp. 45-114.

Cicero, M.T., 1914, De amicitia, IX, Loeb Classical Library, London.

Clanchy, M.T., 1999, Abelard: A Medieval life, Wiley-Blackwell, London.

Compayré, G., 1902, Abelard and the origin and early history of universities, Charles Scribner's Sons, New York.

Copleston, F.C., 1993, A history of philosophy, vol. II, Medieval philosophy, Doubleday, New York.

D’Argenteuil, Héloïse, 1855, Epistola II,Patrologia Latina 178, in J.-P. Migne (ed.), viewed 17 September 2018, from http://patristica.net/latina.

Dronke, P., 1984, Women writers of the Middle Ages, Cambridge University Press, Cambridge.

Dronke, P. (ed.), 1988, A history of twelfth-century Western philosophy, Cambridge University Press, Cambridge.

Georgianna, L., 2000, '“In any corner of heaven”: Heloise's critique of monastic life', in B. Wheeler (ed.), Listening to Heloise: The voice of a twelfth-century woman, pp. 187-216, Palgrave Macmillan, New York.

Gilson, E., 1951, Heloise and Abelard, Henry Regnery, Chicago, IL.

Grabmann, M., 1957, Die Geschichte der scholastischen Methode, vol II, Akademie Verlag, Berlyn.

Guilfoy, K., 2012, 'William of Champeaux', in E.N. Zalta (ed), The Stanford encyclopedia of philosophy, Winter 2012 Uitgawe.

Hamilton, E., 1966, Heloise, Hodder \& Stoughton, Londen.

Haren, M., 1985, Medieval thought: The Western intellectual tradition from antiquity to the thirteenth century, Macmillan, Londen.

Hyman, A., Walsh, J.J. \& Williams, T. (reds.), 2010, Philosophy in the Middle Ages: The Christian, Islamic and Jewish traditions, Hackett, IN.

Interfoto, Abelard, Peter, $1079-2.4 .1124$, French philosopher and theologian, with his beloved Heloise, memorial slab, cemetery Père Lachaise, Paris, France, Additional-Rights-Clearances-NA.

Iwakuma, Y., 1992, 'Vocales, or early nominalists', Traditio 47, 37-111. https://doi. org/10.1017/S0362152900007200

Iwakuma, Y., 1999, 'Pierre Abélard et Guillaume de Champeaux dans les premières années du XIle siècle: Une étude préliminaire', in J. Baird (ed.), Langage, sciences, philosophie au XIle siècle, Vrin, Paris.

Iwakuma, Y, 2006, 'Influence', in Brower \& Guilfoy (reds.), The Cambridge companion to Abelard, pp. 305-335, Cambridge University Press, Cambridge.

Kenny, A., 2005, Medieval philosophy, Clarendon Press, Oxford.

King, P., 2006, 'Metaphysics', in J. Brower \& K. Guilfoy (eds.), The Cambridge companion to Abelard, pp. 65-125, Cambridge University Press, Cambridge.

Levitan, W. (trans.), 2007, Abelard and Heloise: The letters and other writings, Hackett, IN.

Liebeschütz, H., 1967, 'Dialectical skill as a scholar's showpiece', in Armstrong (ed.), The Cambridge history of later Greek and early Medieval philosophy, pp. 593-599, Cambridge University Press, Cambridge.

Luscombe, D., 1970, The school of Peter Abelard: The influence of Abelard's thought in the early scholastic period, Cambridge University Press, Cambridge.

Luscombe, D., 1971, Peter Abelard's ethics, Oxford University Press, Oxford. 
Luscombe, D., 1988, 'Peter Abelard', in Dronke (ed.), A history of twelfth-century Western philosophy, pp. 279-307, Cambridge University Press, Cambridge.

Luscombe, D., 1992, 'The School of Peter Abelard revisited', Vivarium 30, 127-138. https://doi.org/10.1163/156853492X00098

Luscombe, D., 2004, Medieval thought, Oxford University Press, Oxford.

Mann, W.E., 2006, 'Ethics', in J. Brower \& K. Guilfoy (eds.), The Cambridge companion to Abelard, pp. 279-305, Cambridge University Press, Cambridge.

Marenbon, J., 1988, Early Medieval philosophy (488-1150): An introduction Routledge, New York.

Marenbon, J., 1992, 'Vocalism, nominalism and the commentaries on the categories from the earlier twelfth century', Vivarium 30, 51-61. https://doi.org/10.1163/ $156853492 \times 00043$

Marenbon, J., 1997, The philosophy of Peter Abelard, Cambridge University Press, Cambridge.

Marenbon, J., 2000, 'Authenticity revisited', in B. Wheeler (ed.), Listening to Heloise: The voice of a twelfth-century woman, pp. 19-34, Palgrave Macmillan, New York.

Marenbon, J., 2006a, 'Abelard', in J.J.E. Gracia \& T.B. Noone (eds.), A companion to philosophy in the Middle Ages, pp. 485-493, Blackwell, Oxford.

Marenbon, J., 2006b, 'Life, milieu, and intellectual contexts', in J. Brower \& K. Guilfoy (eds.), The Cambridge companion to Abelard, pp. 13-44, Cambridge University Press, Cambridge.

Marenbon, J., 2006c, 'William of Champeaux', in J.J.E. Gracia \& T.B. Noone (eds.), pp. 690-691.

Martin, C.J., 2006, 'Logic', in J. Brower \& K. Guilfoy (eds.), The Cambridge companion to Abelard, pp. 158-199, Cambridge University Press, Cambridge.

Martin, C.J., 2010, 'The development of logic in the twelfth century', in R. Pasnau \& C. van Dyke (eds.), The Cambridge history of Medieval philosophy, vol. 1, pp. 129-145, Cambridge University Press, Cambridge.

McCabe, J., 1972, Peter Abelard, Burt Franklin Research and Source Works Series: Philosophy \& Religious History Monographs 110, Lenox Hill, New York.

McLaughlin, M.M., 2000, 'Heloise the abbess: The expansion of the Paraclete', in B. Wheeler (ed.), Listening to Heloise: The voice of a twelfth-century woman pp. 1-18, Palgrave Macmillan, New York.

McLaughlin, M.M. \& B. Wheeler (trans.\& eds.), 2009, The letters of Heloise and Abelard: A translation of their collected correspondence and related writings, Palgrave MacMillan, New York.

Mews, C.J., 1986, 'On dating the works of Peter Abelard', Archives d'Histoire Doctrinale et Littéraire du Moyen Age 60, 73-134.

Mews, C.J., 1995, Peter Abelard: Authors of the Middle Ages II 5, Variorum, Aldershot.
Mews, C.J., 2000, 'Philosophical themes in the Epistolae duorum amantium', in B. Wheeler (ed.), Listening to Heloise: The voice of a twelfth-century woman, pp. 35-52, Palgrave Macmillan, New York.

Mews, C.J., 2005, Abelard and Heloise, Oxford University Press, Oxford.

Mews, C.J. \& Jolivet, J., 1990, 'Peter Abelard and his influence', in G. Floistad (ed.), Contemporary philosophy 6/1: Philosophy and science in the Middle Ages, pp. 105-40, Kluwer, Amsterdam.

Pinzani, R., 2003, The logical grammar of Abelard, Kluwer, Dordrecht.

Price, B.B., 1992, Medieval thought: An introduction, Blackwell, Oxford.

Russell, B., 1945, A history of Western philosophy, Simon \& Schuster, New York.

Smalley, B., 1981, Studies in Medieval thought and learning: From Abelard to Wyclif, The Hambledon Press, Londen.

Spade, P.V. (trans. \& (red.)), 1994, Five texts on the medieval problem of universals: Porphyry, Boethius, Abelard, Duns Scotus, Ockham, Hackett, IN

Sweeney, E.C., 2006a, Logic, theology, and poetry in Boethius, Abelard, and Alan of Lille: Words in the absence of things, Palgrave MacMillan, New York.

Sweeney, E.C., 2006b, 'Abelard: A twelfth-century hermeneutics of suspicion', in E.C. Sweeney, Logic, theology, and poetry in Boethius, Abelard, and Alan of Lille: Words in the absence of things, pp. 63-126, Palgrave MacMillan, New York.

Tweedale, M.M., 1976, Abailard on universals, North-Holland, Amsterdam.

Tweedale, M.M., 1982, 'Abelard and the culmination of the old logic', in N. Kretzmann, A. Kenny \& J. Pinborg (eds.), The Cambridge history of later Medieval philosophy, pp. 143-158, Cambridge University Press, Cambridge.

Tweedale, M.M., 1988, 'Logic (i): From the late eleventh century to the time of Abelard', in P. Dronke (ed.) 1988, Women writers of the Middle Ages, pp. 196-226, Cambridge University Press, Cambridge.

Wadell, H., 2008, Peter Abelard, Bucks Press, Bubuashie.

Waithe, M.E., 1989a, 'Heloise', in M.E. Waithe (ed.), A history of women philosophers. Volume II. Medieval, Renaissance and Enlightenment women philosophers, pp. 67-84, Kluwer, Dordrecht.

Waithe, M.E. (ed.), 1989b, A history of women philosophers, vol. II, Medieval, Renaissance and Enlightenment women philosophers, Kluwer, Dordrecht.

Ward, J.O. \& Chiavaroli, N., 2000, 'The young Heloise and Latin rhetoric', in B. Wheeler (ed.), Listening to Heloise: The voice of a twelfth-century woman, pp. 53-120 Palgrave Macmillan, New York.

Wheeler, B. (ed.), 2000, Listening to Heloise: The voice of a twelfth-century woman, Palgrave Macmillan, New York.

Wilks, I., 2008, 'Peter Abelard and his contemporaries', in D. Gabbay \& J. Woods (eds.) Medieaval and Renaissance logic, pp. 83-156, Elsevier, Amsterdam. 